\title{
Evaluation of Body Mass Index of 3-10-year-old Children with Adenotonsillar Hypertrophy, who Referred to Khatamolanbia Hospital during 2017-2018
}

\author{
Gholam-Ali Dashti Khavidaki, Reza Gharibi* \\ Department of ENT Disorder, AL-Zahra Hospital, Zahedan University of Medical Sciences, Zahedan, Iran
}

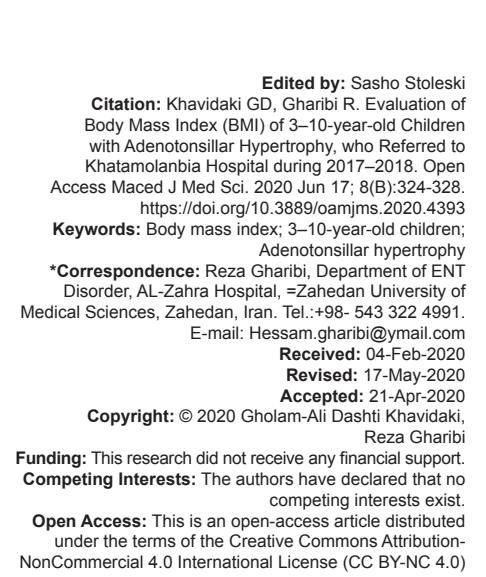

\section{Abstract}

BACKGROUND: Adenotonsillar hypertrophy is a common disorder in the children's population that can lead to growth disorders. Chronic adenotonsillar hypertrophy can cause a break in the normal growth of children, weight loss, and decreased growth hormone secretion.

AIM: The purpose of this study was to evaluate adenotonsillar hypertrophy in the growth rate of children with height weight, and body mass index (BMI).

METHODS: In this descriptive-analytical cross-sectional study, after examining 312, 3-10-year-old children with adenotonsillar hypertrophy, who met the inclusion criteria, growth scales were evaluated and entered into the patient evaluation form.

RESULTS: There was a significant relationship between BMI, height, weight, and severity of tonsillar hypertrophy at Brodsky's scale $(P<0.001)$. Our studies showed well that with increasing severity of adenotonsillar hypertrophy disease, the growth indicators are also decreased in children.

CONCLUSION: Adenotonsillar hypertrophy decreases growth indicators in children. There was also a relationship between growth indicators and severity of adenotonsillar hypertrophy in patients.

\section{Introduction}

Adenotonsillar hypertrophy is a common disorder in the children population that causes an obstruction in the nasal route and eustachian tube and prevents drainage of nasal mucus [1]. The common clinical signs of adenotonsillar hypertrophy include nasal congestion, which results in sleep disorders from snoring to obstructive sleep apnea, rhinorrhea, oral respiration, hyponasal speech, and cough [2].

Obstructive sleep apnea, as one of the most damaging disorders of adenotonsillar hypertrophy, leads to frequent hypoxia and sleep disturbances, which can have adverse effects on the cognitive and behavioral nervous evolution of children as well as cardiovascular disorders. Another disorder that patients with adenotonsillar hypertrophy and airway obstruction may encounter is developmental disorders. Chronic adenotonsillar hypertrophy and subsequent upper airway obstruction appear to cause a disruption in the normal growth of children [3], [4], [5] and weight loss [6]. Several studies have also indicated that adenotonsillar hypertrophy and its subsequent sleep apnea are along with slow growth and weight gain in infants and babies [7], [8], [9]. These disorders are due to a number of factors such as decreased growth hormone secretion in the sleep phase, decreased insulinlike growth factor 1 (IGF-I) [3], [10], as well as decreased energy intake due to difficulty swallowing and increased energy consumption during the sleep [11].

Due to the importance of the proper growth and weighting process in children and its close relationship to children's health, responsible health systems, especially in developed countries are spending large amounts of money on monitoring and controlling this process in children to identify and resolve the factors that have a negative impact on that [12].

The purpose of this study was to investigate the relationship between body mass index (BMI) and adenotonsillar hypertrophy in children.

\section{Materials and Methods}

\section{The study population}

In this study, all referral children with adenotonsillar hypertrophy to the clinics of 
Khatamolanbia Hospital during the 2017-2018 were evaluated. Inclusion criteria were adenotonsillar hypertrophy, 3-10 years old, and patient satisfaction, and no history of any other concomitant disease to participate in the study.

\section{Procedure}

This study was a descriptive-analytical observational study and included 312 children with the age of 3-10 years with adenotonsillar hypertrophy, whose parents were consenting to participate in the study. Age and sex information were collected by asking from parents. The intensity of tonsillar hypertrophy was determined based on Brodsky's scale, where; zero: Tonsil did not affect airway; +1 intensity: Affect the airway $<25 \%$; +2 intensity: Affect the airway between 25 and 50\%; +3 intensity: Affect the airway between $50-75 \%$, and +4 intensity: Affect the airway over $75 \%$. In addition, the weight of these children with lightweight clothing without shoes was measured by a pointer scale with a measuring error of $100 \mathrm{~g}$, and their height without shoes was also measured with a $5 \mathrm{~mm}$ accuracy height meter.

\section{Statistical analysis}

The obtained information was recorded in data collection forms. After completing the sampling, data were analyzed in SPSS software version 22.

\section{Results}

\section{BMI}

The mean BMI was $(85 / 87 \pm 38 / 43)$ in the evaluation of patients based on BMI percentile, which among them, the mean BMI for boys was calculated $(37 / 38 \pm 42 / 34)$ and for girls $(01 / 30 \pm 13 / 66)$. There was no significant relationship between $\mathrm{BMI}$ percentile and age of patients ( $p<0.151)$, but there was a significant relationship between this variable and $\operatorname{sex}(p<0.001)$.

Statistical analysis also showed a significant difference between the severity of adenotonsillar hypertrophy (Brodsky's scale) and BMI ( $p<0.001$ ). It should be noted that the correlation between the severity of adenotonsillar hypertrophy and BMI was $\mathrm{R}=-0.69$, which indicating a moderate and inverse correlation. Table 1 summarizes the results of statistical analyzes on BMI.

\section{Height growth}

The calculated relationship between age and height growth showed that with increasing age, the
Table 1: Impact of age, gender, and severity of adenotonsillar hypertrophy on BMI (by percentile) of children with adenotonsillar hypertrophy, who referred to Khatamolanbia Hospital during 2017-2018

\begin{tabular}{clll}
\hline Variable & Mean BMI by percentile & Standard deviation & Value of $p$ \\
\hline Age (year) & & & \\
3 & $45 / 59$ & $44 / 20$ & $\mathrm{p}<0 / 151$ \\
4 & $71 / 07$ & $28 / 87$ & \\
5 & $39 / 70$ & 0 & \\
6 & $27 / 56$ & $35 / 64$ & \\
7 & $0 / 36$ & $0 / 25$ & \\
8 & $3 / 6$ & 0 & \\
9 & 4 & 0 & \\
10 & $68 / 94$ & $25 / 72$ & \\
Sex & & & \\
Male & $34 / 42$ & $38 / 37$ & \\
Female & $66 / 13$ & $30 / 01$ & \\
Adenotonsillar hypertrophy by Brodsky scale & & \\
0 & $18 / 60$ & $2 / 17$ & \\
1 & $20 / 08$ & $3 / 48$ & \\
2 & $15 / 38$ & $1 / 14$ & \\
3 & $14 / 30$ & $1 / 45$ & \\
4 & $14 / 11$ & $32 / 35$ & \\
Total & $43 / 87$ & $38 / 85$ & \\
\hline BMI: Body mass index. & & \\
& & &
\end{tabular}

mean height also shows an increasing and significant correlation between age and height of people $(p<0.001)$ and strong and direct correlation $(R=0.96)$.

Further reviews on height showed that the mean height in males was (83/16 $\pm 47 / 113)$ and in females was $(48 / 15 \pm 55 / 106)$, and there was a significant relationship between sex and height of patients ( $p<0.002)$.

There was no significant relationship between height index and intensity of Tonsillar hypertrophy based on Brodsky's scale $(p=0.07)$ and there was a positive and weak correlation between these two criteria

Table 2: Impact of age, gender, and severity of adenotonsillar hypertrophy on the height growth process of children with adenotonsillar hypertrophy, who referred to Khatamolanbia Hospital during 2017-2018

\begin{tabular}{clll}
\hline Variable & Mean height & Standard deviation & Value of $p$ \\
\hline Age (year) & & & \\
3 & $90 / 23$ & $2 / 10$ & $\mathrm{p}<0 / 001$ \\
4 & $97 / 23$ & $4 / 55$ & \\
5 & 106 & 0 & \\
6 & $107 / 42$ & $2 / 47$ & \\
7 & $114 / 93$ & $1 / 01$ & \\
8 & 124 & 0 & \\
9 & 126 & 0 & \\
10 & $130 / 51$ & $10 / 12$ & \\
Sex & $113 / 47$ & $16 / 83$ & \\
Male & $106 / 55$ & $15 / 48$ & \\
Female & & & \\
Adenotonsillar hypertrophy by Brodsky scale & & \\
0 & $109 / 87$ & $24 / 27$ & \\
1 & $109 / 05$ & $21 / 82$ & \\
2 & $114 / 86$ & $11 / 70$ & \\
3 & $112 / 29$ & $12 / 68$ & \\
4 & $110 / 77$ & $13 / 46$ & \\
Total & $111 / 41$ & $16 / 72$ & \\
\hline
\end{tabular}

$(R=0.21)$. In Table 2 was showed the relationship between age, sex, and severity of adenotonsillar hypertrophy with height growth.

Weight: Similar to the relationship between age and height, there was a significant relationship between age and weight of participants $(p<0.001)$ and the correlation between them $(R=0.88)$ indicated a strong and direction relationship. 
Table 3: Impact of age, gender, and severity of adenotonsillar hypertrophy on the weight rate of children with adenotonsillar hypertrophy, who referred to Khatamolanbia Hospital during 2017-2018

\begin{tabular}{clll}
\hline Variable & Mean weight & Standard deviation & Value of $\mathbf{p}$ \\
\hline Age (year) & & & \\
\hline 3 & $13 / 36$ & $1 / 99$ & $\mathrm{p}<0 / 001$ \\
4 & 16 & 0 & \\
5 & 17 & 0 & \\
6 & $16 / 95$ & $0 / 82$ & \\
7 & $15 / 6$ & $1 / 52$ & \\
8 & 21 & 0 & \\
9 & 22 & 0 & $\mathrm{p}=0 / 34$ \\
10 & 33 & $9 / 18$ & \\
Sex & & & \\
Male & $21 / 51$ & $10 / 54$ & \\
Female & $19 / 69$ & $5 / 86$ & \\
Adenotonsillar hypertrophy by Brodsky scale & & \\
0 & $24 / 21$ & $13 / 16$ & \\
1 & $25 / 66$ & $13 / 53$ & \\
2 & $20 / 67$ & $5 / 25$ & \\
3 & $18 / 44$ & $4 / 95$ & \\
4 & $17 / 65$ & $5 / 63$ & \\
Total & $20 / 97$ & $9 / 42$ & \\
\hline
\end{tabular}

The calculated weighted mean in males was $(54 / 10 \pm 51 / 21)$ and $(86 / 5 \pm 69 / 19)$ in females. There was no significant relationship between sex and weight of patients $(p=0.34)$ (Table 3$)$. Calculations showed that weight and intensity of Tonsillar hypertrophy based on Brodsky's scale a significant relationship between inverse and mean correlation $(p<0.001)(R=0.22)$.

\section{Discussion}

The nose and oral area has a growing lymphoid tissue [13]. Tonsillar hypertrophy is the most common cause of laryngeal obstruction and sleeprelated respiratory disorders. Obstructive sleep apnea is a common disease in children with adenotonsillar hypertrophy syndrome. Some of the factors caused by adenotonsillar hypertrophy including too loud snoring, chronic oral breathing, frequent waking at night, excessive drowsiness, nightmares, poor educational performance, and dysphagia. Children with obstruction caused by tonsillar hypertrophy usually eat less and have a lower weight percentage due to loss of appetite [13].

Among the 312 studied patients, $70.2 \%$ were male and $29.8 \%$ were female. Obviously, in different studies, the proportion of these communities is also different [12], [14], [15], and the reason for this difference is the sampling in different study communities, the population under study, and the male and female populations of different geographic areas. As noted in the findings section, sex was significantly associated with BMI percentile and height. However, there was no relationship between sex and weight of patients. The reason for this can be attributed to the heterogeneity of male and female populations in this study.

The relationship between age and adenotonsillar hypertrophy is somehow that most studies have been stated that age before 15 is the age of diagnosis. The mean age of the study population was $(6 / 2 \pm 53 / 72)$ and statistical analysis showed a significant relationship between age and weight and height growth so that the correlation between age and these two variables showed their direct and strong relationship, and in both male and female, by weight increasing and despite adenotonsillar hypertrophy, the height and weight of the child also increase.

In evaluating the relationship of adenotonsillar hypertrophy with BMI, it was found that BMI in growth percentiles was very low in $40.1 \%$ of patients, and also $40.4 \%$ had proportional weight to age, while $5.1 \%$ was overweight, and $14.4 \%$ had too much weight (obese). In previous studies, BMI percentiles below 2 were malnourished, between 2 and below 91 were normal, and above 91 considered obese, whereas in our study, based on the latest reference changes, the percentiles below $5 \%$ were low weight, $50 \%$ to $85 \%$ were proportional, and $85 \%$ to $95 \%$ were overweight and above $95 \%$ were obese [16].

Our study indicated that a large population of people with adenotonsillar hypertrophy did not have adequate weight gain. The cause of this can be traced to the effect of adenotonsillar hypertrophy on metabolism. In the Lumeng and Herrmann experiments, it has been demonstrated that chronic adenotonsillar hypertrophy can increase calorie intake and energy loss and consequently impair the development of children [17], [18].

The mean height of 312 patients in our study

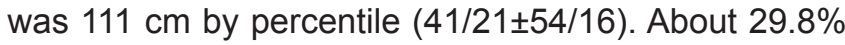
of patients had short height, $65.1 \%$ moderate height, and $5.1 \%$ taller than normal. The mean weight of children in this study was $20 \mathrm{~kg}$ which was calculated $(19 / 33 \pm 32 / 27)$ by percentile. This data indicate growth delay in the studied groups in terms of BMI and height and weight. Thus, it can be observed that, are consistent with other studies, chronic adenotonsillar hypertrophy can impair the normal growth process [8], [19].

It has been proven today that obstructive apnea caused by adenotonsillar hypertrophy, decreases the secretion of growth hormone IGF [20].

IGF-1 is a growth factor that has endocrine and paracrine effects and its secretion is controlled by growth hormone. Most of the existing IGF-1 carries the bond protein that it is called IGF binding protein-3 (IGF BP3).

IGF BP3 synthesis is also controlled by growth hormone. Levels of IGF-1 are applied, so serum levels of IGF BP3 and IGF-1 are considered to evaluate growth hormone levels [8].

Park tests showed that after adenotonsillar surgery, the serum IGF1 levels [21] and height were increased, and the increasing of weight is obvious [15].

In addition to the effect of adenotonsillar hypertrophy on the growth IGF-1 hormone secretion, 
it seems that it can provide a suitable substrate for the growth of pathogenic bacteria, especially betalactamase-producing groups in tonsillar and adenoid tissue. Growth of bacteria along with obstructive apnea in chronic adenotonsillar hypertrophy can increase metabolism and calorie consumption and subsequently impaired child development [17], [18].

In the reviews of 61 adenotonsillectomized children and comparing them with other 31 healthy children found that troubleshooting such as sleep apnea, nocturnal hypoxia, and sleep disorders, with adenotonsillar surgery, led to an increase in all children.

In the study of growth phenomena and its chemical markers [22], [23] in children with obstructive sleep apnea due to adenotonsillar hypertrophy, 70 children were studied as patients and 35 children as a control group for IGF BP3 and IGF-1. This study showed that during the post-operative phase, the ratio of weight to height and secretion of IGF-1 and IGF-BP3 increased [24].

\section{Conclusion}

In this study, we observed a decrease in growth indicators in children with adenotonsillar hypertrophy (height, weight, and BMI). Furthermore, there was a relationship between growth indicators and severity of adenotonsillar hypertrophy in patients.

\section{References}

1. Hellings PW, Fokkens WJ. Allergic rhinitis and its impact on otorhinolaryngology. Allergy. 2006;61(6):656-64. https://doi. org/10.1111/j.1398-9995.2006.01109.x

PMid:16677233

2. Choudhary B, Patil R, Bhatt GC, Dhingra B, Pakhare AP, Goyal A, et al. Association of sleep disordered breathing with mono-symptomatic nocturnal enuresis: A study among school children of central India. PLoS One. 2016;11(5):e0155808 https://doi.org/10.1371/journal.pone.0155808

PMid:27191620

3. Bonuck KA, Freeman K, Henderson J. Growth and growth biomarker changes after adenotonsillectomy: Systematic review and meta-analysis. Arch Dis Child. 2009;94(2):83-91. https:// doi.org/10.1136/adc.2008.141192

PMid: 18684748

4. Brodsky L, Koch RJ. Bacteriology and immunology of normal and diseased adenoids in children. Arch Otolaryngol Head Neck Surg. 1993;119(8):821-9. https://doi.org/10.1001/ archotol.1993.01880200021003

PMid:8343242

5. Brodsky L, Radomski K, Gendler J. The effect of post-operative in structions on recovery after tonsilectomy and adenoidectomy. Int J Pediatr Otorhinolaryngol. 1993;25(1-3):133-40. https://doi. org/10.1016/0165-5876(93)90046-6

PMid:8436457

6. Bland RM, Bulgarelli S, Ventham JC, Jackson D, Reilly JJ, Paton JY. Total energy expenditure in children with obstructive sleep apnoea syndrome. Eur Respir J. 2001;18(1):164-9. https://doi.org/10.1183/09031936.01.99104401

PMid:11510789

7. Capdevila OS, Kheirandish-Gozal L, Dayyat E, Gozal D. Pediatric obstructive sleep apnea: Complications, management, and long-term outcomes. Proc Am Thorac Soc. 2008;5(2):27482. https://doi.org/10.1513/pats.200708-138mg

PMid:18250221

8. Williams EF $3^{\text {rd }}$, Woo P, Miller R, Kellman RM. The effects of adenotonsillectomy on growth in young children. Otolaryngol Head Neck Surg. 1991;104(4):509-16. https://doi. org/10.1177/019459989110400415 PMid:1903865

9. Leach J, Olson J, Hermann J, Manning S. Polysomnographic and clinical findings in children with obstructive sleep apnea. Arch Otolaryngol Head Neck Surg. 1992;118(7):741-4. https:// doi.org/10.1001/archotol.1992.01880070071013

PMid:1627296

10. Walker MP, Diaugustine RP, Zeringue E, et al. An IGF1/insulin receptor substrate-1 pathway stimulates a mitotic kinase (cdk1) in the uterine epithelium during the proliferative response to estradiol. J Endocrinol. 2010;207(2):225-35. https://doi. org/10.1677/joe-10-0102

PMid:20798132

11. Greg R, Raymond C. Creative tourism. ATLAS News 2000;23:16-20.

12. Richart H. Tarascon Pocket Pharmacopoeia 2015 Deluxe Lab-coat Edition. United States: Jones \& Bartlett Learning; 2015. p. 349.

13. Izu SC, Itamoto $\mathrm{CH}$, Pradella-Hallinan $\mathrm{M}$, Pizarro $\mathrm{GU}$, Tufik S, Pignatari S, et al. Obstructive sleep apnea syndrome (OSAS) in mouth breathing children. Braz J Otorhinolaryngol. 2010;76(5):552-6.

PMid:20963335

14. Daar G, Sarı K, Gencer ZK, Ede H, Aydın R, Saydam L. The relation between childhood obesity and adenotonsillar hypertrophy. Eur Arch Otorhinolaryngol. 2016;273(2):505-9. https://doi.org/10.1007/s00405-015-3554-4 PMid:25876003

15. Farmarzi M, Shishegar M, Heydari ST, Haghighi A, Sharouny H. Effects of adenotonsillectomy on serum levels of IGF-1 and IGFBP-3 and growth indices in children with adenotonsillar hypertrophy or recurrent tonsillitis. Iran J Otorhinolaryngol. 2016;28(88):329-35. PMid:27738609

16. Egeli E, Belli SB, Oghan F, Ozturk O. Relation of isolated tonsillar hypertrophy with body mass index. ORL J Otorhinolaryngol Relat Spec. 2006;68(4):228-31. https://doi.org/10.1159/000092124 PMid: 16549938

17. Hable KA, Washington JA $2^{\text {nd }}$, Herrmann EC Jr. Bacterial and viral throat flora. Comparison of findings in children with acute upper respiratory tract disease and in healthy controls during winter. Clin Pediatr (Phila). 1971;10(4):199-203. https://doi. org/10.1177/000992287101000405 PMid:4396432

18. Lumeng JC, Chervin RD. Epidemiology of pediatric obstructive sleep apnea. Proc Am Thorac Soc. 2008;5(2):242-52. PMid:18250218

19. Schiffmann R, Faber J, Eidelman Al. Obstructive hypertrophic adenoids and tonsils as a cause of infantile failure to thrive: 
Reversed by tonsillectomy and adenoidectomy. Int J Pediatr Otorhinolaryngol. 1985;9(2):183-7. https://doi.org/10.1016/ s0165-5876(85)80019-7

\section{PMid:4030240}

20. Ahlqvist-Rastad J, Hultcrantz E, Melander H, Svanholm H. Body growth in relation to tonsillar enlargement and tonsillectomy. Int J Pediatr Otorhinolaryngol. 1992;24(1):55-61. https://doi. org/10.1016/0165-5876(92)90066-x PMid:1399304

21. Park DY, Choi JH, Kang SY, Han J, Park HY, Hwang JS, et al. Correlations between pediatric obstructive sleep apnea and longitudinal growth. Int J Pediatr Otorhinolaryngol. 2018;106:41-5. PMid:29447889

22. Gibb AG. Unusual complications of tonsil and adenoid removal.
J Laryngol Otol. 1969;83(12):1159-74. https://doi.org/10.1017/ s0022215100071486

PMid:5360031

23. Nieminen $P$, Löppönen $T$, Tolonen $U$, Lanning $P$, Knip $M$, Löppönen $H$. Growth and biochemical markers of growth in children with snoring and obstructive sleep apnea. Pediatrics. 2002;109(4):e55. https://doi.org/10.1542/peds.109.4.e55 PMid:11927728

24. Bar A, Tarasiuk A, Segev Y, Phillip M, Tal A. The effect of adenotonsillectomy on serum insulin-like growth factor-I and growth in children with obstructive sleep apnea syndrome. J Pediatr. 1999;135(1):76-80. https://doi.org/10.1016/ s0022-3476(99)70331-8

PMid: 10393608 